\title{
DRIVING IN OCTOBER, I BURST INTO TEARS
}

A deeply loving schizophrenic man of forty-five, my son has spent the day helping me rip out the frostkilled remnants of the garden, put away the tools,

hoses, lawn chairs-the season. I've taken him home to his lonely apartment, an hour away, and am returning to my un-lonely house, and Elena, at work on an article.

I'm driving into the west an hour after sunset, NPR on the radio, an actor named Robbie Coltrane-who played Hagrid in the Harry Potter movies-talking

about his new hit TV show called "Incredible Britain." Each week he takes a crew to some little backwater village and films the live-action of a local tradition.

In one show, the populations of two adjacent towns vie to kick, carry, throw, or otherwise propel a small keg of beer some miles across the line into their town first-

hundreds battle, with no rules but the unwritten one of no killing. This tradition, says Robbie, goes back to Roman England. “There's about eleven or twelve

hundred people," he says, in his lilting burr: "It's like the biggest rugby scrum on the face of the earth!" Just then I crest a hill at sixty on the empty two-lane blacktop ribboning through these central New York farmlands-where one town once tried to start a tradition of making the world's largest pancake but sustained it 
for only one year-and up ahead high on the next rise behold a streetlight glowing a civilized electric yellow against the ocean-green expanse of the evening sky,

cloud-tracked and apricot-smudged-and I burst into tears. There could be a TV show called "Incredible Everything" and the thought of leaving everything forever in another

decade or so undoes me. My vision blurred, I feel a front tire hit the gravel shoulder and I jerk the wheel sharply, thinking, what would my son say about this sentimental

applauding of the world's wonders? "Better to keep your eyes on the daggone road, father," I guess, and, thinking I'm going to laugh out loud, I burst into tears again-

82

though whether out of euphoria or despair, I couldn't say. Well-yes, I probably could, if it mattered. But it doesn't. What does though is how incredible it is that it doesn't. 